\title{
Aporias in Literary Translation: A Case Study of The Prophet and Its Translations
}

\author{
Maya El Hajj \\ Department of English and Translation, Notre Dame University-Louaize, Beirut, Lebanon
}

\begin{abstract}
Literary translation is one of the most challenging tasks in the field of translation. This paper focuses on the aporias in literary texts written and/or translated into Arabic, French, Italian, and English. I contend that some terms/phrases are difficult to render in the target text. This argument is bolstered by examples extracted from The Prophet of the Arabo-American author Gibran Kahlil Gibran. I selected this particular oeuvre given its immense success in terms of vast cultural diffusion and translation into various languages. Also, The Prophet, has been translated several times into the same target languages in addition to the large number of languages to which it has been rendered. I will discuss the translator's dilemma when undertaking the task of faithfully conveying the aesthetics of the original text into the same, or into the closest version of the original. This paper concentrates on the cultural differences between languages by emphasizing on untranslatability and various retranslations. It analyzes how these elements were rendered into the target culture and language. The argument put forth in this paper attempts to shed light on the importance of literary translation, as one of the most critical discourses of translation.
\end{abstract}

Index Terms - literary translation, The Prophet, retranslation, Gibran Kahlil Gibran, languages

\section{INTRODUCTION}

This paper centers on the aporias in literary texts written and/or translated into Arabic, French, Italian, and English. I assert that some terms/phrases are practically difficult to render in the target text; and, when rendered, the difficulty of the original or the lack of research or knowledge of the translator, the misinterpretation of the source text or simply the cultural differences will result in an output of significantly negative quality. I support this argument with typical examples, extracted from the renowned Arabo-American author, Gibran Kahlil Gibran and his masterpiece, written in English, The Prophet. I will discuss the translator's dilemma when undertaking the task of faithfully conveying the aesthetics of the original text into the closest, level of the original. As mentioned earlier, I selected this particular work taking into account its accomplishment in terms of multi-cultural diffusion and translation into numerous languages. These examples serve to demonstrate the arduous task and immense responsibility the literary translator faces. In addition, I refer to the example of The Prophet that has been retranslated several times (see Appendix A) into the same target language, Italian and French, besides the large number of languages in different geographic regions to which it has been translated (see Fig.1). Europe had the highest share of the number of translations of the first edition of The Prophet followed by Asia, attesting to the European and Asia interest in this type of literary translations probably due to their artistic aura that meant to him a great deal.

The Prophet lives in Orphalese for almost a period of twelve years. He is about to board a ship to go back home when he is interrogated by a group of people with whom he has conversed about topics related to life. The themes of the book deal with love, marriage, children, joy, sorrow, freedom, passion, friendship, prayer, beauty, religion, death etc. Quoting Alexandre Najjar (2018) in the preface of a recent study on The Prophet in an Arabic and French comparative linguistic analysis: "The undisclosed value of this work, which remains beyond genre classification, lies in its message; it is simple yet profound, transmitted in a poetic language imbued with imagery..." We notice that The Prophet presents its author's thoughts in a limpid and accessible manner; thus, all readers are able to savour it and draw life lessons". Gibran, when asked about the global need of The Prophet, could not help but answering that it was The Prophet that wrote him and not the opposite (Bushrui, 1970). Hence, I will undertake a comparative and analytical study at this stage, by scrutinizing the rationale behind retranslations in several cases. So, the intention is to examine the evolution of these translations and their assorted shortcomings. It is commonly known that translators embark on a lengthy process of research when it involves translating literary works before rendering the final output. This study will define this preparatory stage, establishing that when one item is missed the whole process - and eventually the final productbecomes incomplete or suffers major gaps. I will gradually shift from theories towards practical examples and highlight major difficulties at this level. 


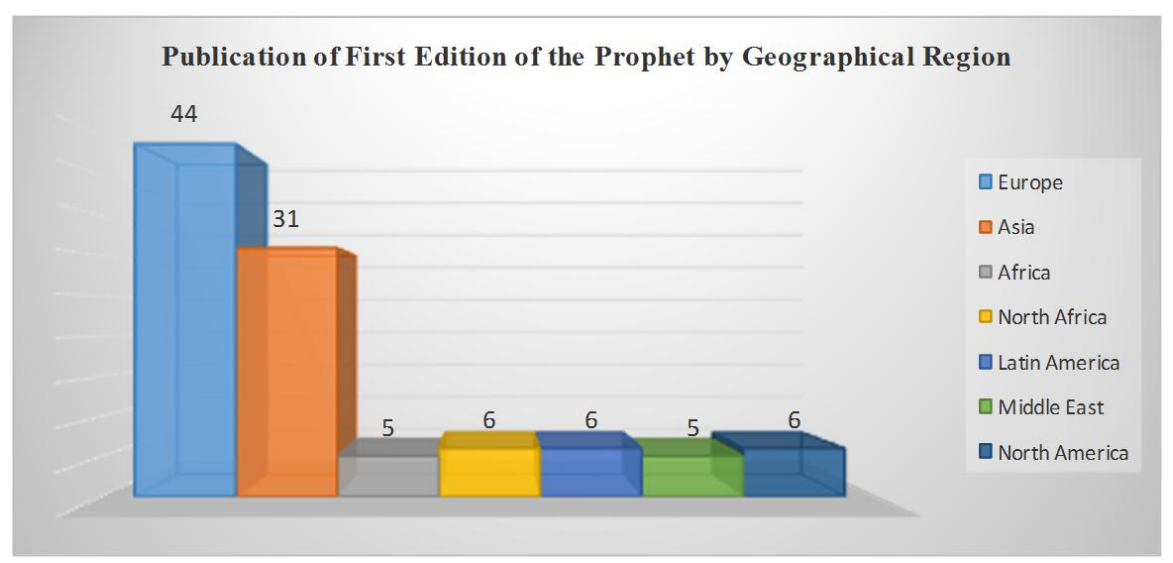

Figure 1: Publication of First Edition of The Prophet by Geographical Region

\section{REVIEW OF LITERATURE}

Literary translation requires a high level of meticulousness. In order to render a literary text faithfully, one has to make sure that the message is rendered at all levels even when some untranslatable items occur or some foreign concepts prevail. "The translatability of linguistic structures would have to be considered even if they were untranslatable for human beings" (Benjamen, 2012, p.75). Thus, Benjamen raises an important controversial issue stating that if translation is intended for the reader then the original has to be also intended to the reader, and if it is not intended for the reader then how can this relationship allow us to understand the translation (ibid.). Accordingly, the translatability of linguistc structures has to be considered even if they are untranslatable for human beings (ibid. p.76). Apparent untranslatability results from structural incompatibilities between languages; then one can respond with potential translatability, with the possibility of expressing the concepts of human experience in any human language (Wilss, 1982). Von Goethe (2012) states that translation attempts to identify itself with the original; ultimately, it comes close to an interlinear version and greatly facilitates the understanding of the original source text. Translators are compelled and ledback to the source text. The circle is complete within foreign and familiar elements, known and unknown. At this level, one may wonder of the utility of retranslation for the sake of overcoming some translation hurdles. Some translators retranslate some texts retranslated many times before. In an attempt to understand how can retranslation overcome some technical problems at the linguistic, cultural and stylistic levels. Deane- Cox (2014), in a study on Retranslation, starts with the premise that all literary translation is an act of interpreting which crystallizes a number of a conscious or unconscious misreadings of a given source text. Such readings are not solely determined by the source text and the source culture but also by values, beliefs, and representations in the target culture. Each retranslation will demonstrate how it is shaped by its socio-cultural conditions. Nasr (2018) highlights the same idea stating that more than one translation of The Prophet was achieved in Arabic and that some discrepancies exist between the different Arabic versions due to the socio-cultural backgrounds of the translator as it places so much pressure on his/her stylistic idiosyncracies. If, according to Nasr, the first translation mentioned in our study that goes back to Antonios Bashir, is done during the time Gibran was alive, then what is the utility of the other versions?

\section{METHODOLOGY}

This paper employs discourse analysis of literay text of The Prophet translated into Arabic, French, Italian, and English. According to Blommaert and Bulcaen (2000), critical discourse analysts examine wide-ranging topics, including political discourse, ideology, racism, economic discourse, media language, gender, institutional discourse and education. This study employs discourse analysis to examine cross-cultural renditions through the prism of literary text taking The Prophet as a comparative case study. Broadly, critical discourse analysis of documents offers the possibility of illustrating certain aspects of aporias in literary translation highlighting challenges related to the accuracy of the renditions of the meanings reflecting particularities of each culture. This process includes interpretation of published material as a resource for analyses and syntheses (Fairclough, 1989) which is the subject of this paper. In particular, the paper focuses on the cultural differences in the several translations of The Prophet and analyzes how these elements were rendered into the target culture and language. The paper highlights the importance of literary translation, placing and considering it among the hardest in the translation field, and raising many critical issues at this level. I will be undertaking a comparative and analytical study at this level, rationalizing the utility asnd challenges of retranslations in several cases.

\section{Research Questions}

This paper seeks to answer the following research questions:

1- How can we remedy some terms or expressions that are difficult to render to the target language?

2- Did the translators accomplish their mission faithfully? 
3- What is the utility of several retranslations into the same target languages?

4- How could recent quantitative studies highlight the importance of The Prophet?

Procedure

1- Unpublished data were obtained from an Italian colleague F. Medici and a Lebanese Austalian colleague G. Kalem.

2- Those instruments led to the analysis of many aspects at the cultural and linguistic levels.

3- I analyzed the translated versions of The Prophet in Arabic, French, Italian, and English.

4- I perused the several retranslations into the same target language, Italian and French.

5- Key words related to Translation Studies were adopted for word crunching to provide solid evidence for this endeavor.

\section{ANALYSIS}

\section{a. Analysis}

First, let us briefly introduce the Arabic, French and Italian translators of The Prophet that are mentioned in this study. I selected for the current study two translators for the Arabic versions, Antonios Bashir and Sarwat Akacha, and three for the French texts. The first is Paul-Jean Franceschini 1995; the second is Jean Pierre Dahdah: his translation dates back to June 10, 1993. The third, prefaced by Amin Maalouf, was equally achieved in 1993 by Janine Levy. In addition to our close collaboration with Francesco Medici's translation, various versions executed in Italian are mentioned throughout the study, as well. It is essential to note that many celebrated translators of the authors involved in this paper were either regarded skeptically -such as Francesco Medici and Jean Pierre Dahdah- who have so far translated most, if not all, of Gibran's archive, or closely examined. As researchers, we also scrutinized them meticulously. Some critics highlighted cultural difficulties, others, linguistic hurdles, and, in some cases, philosophical values and various complex ideas. The Prophet may be considered a mystical, poetic work expressed in prose-and/or a selection of poems. Such work has complexities and difficulties at several levels. It makes the translator proceed through many stages before attaining the final output and impel a lengthy mental process based on research and knowledge of the target culture. When it concerns assessing a literary translation, one often wonders whether the translator has accomplished the mission work faithfully. However, due to the arduousness of this task, some essential or extremely crucial elements may be overlooked. I will start my analysis by providing a few examples that confirm the importance of mastering soundly the object of the translation task, taking into account the concept of foreignization and domestication (Venuti, 2008).

\section{b. Findings}

The first practical example will shed lights on this issue:

English: The original text in English of (which work- The Prophet) reads like this: "Then the gates of his heart were flung open, and his joy flew far over the sea. And he closed his eyes and prayed in the silences of his soul." (The Prophet )

The Italian translation: "Allora d'improvviso gli si spalancarono le porte del cuore e la sua gioia volò lontano sulle onde. Chiuse gli occhi e pregò nei silenzi della sua anima." (Il Profeta, translated by Francesco Medici)

The French selected translations:

1-"Alors s'ouvrirent toutes grandes les portes de son coeur. Sa joie s'envola sur les flots. Et ses yeux se fermèrent, pour qu'en silence puisse prier son âme." (Le Prophète, Paul- Jean Franceschini)

2-"Les écluses de son coeur furent grandes ouvertes, et sa joie s'envola par-delà les flots. Puis, les yeux clos, il se recueillit dans les silences de son âme. (Le Prophète, translated by Jean- Pierre Dahdah)

3-“Alors les portes de son coeurs s'ouvrirent à la volée et sa joie s'élanca au loin, par dessus la mer. Et il ferma les yeux et il pria dans les silences de son âme." (Le Prophète, translated by Jeanne Levy).

The Arabic translation:

"فاختلج قلبه في أعماقه وطارت روحه فوق البحر فرحاً، فأغمض عينيه ثم صلى في سكون نفسه" (The Prophet, translated by Antonios Bashir)

This straightforward example, "The silences of his soul", demonstrates accurately who truly understood Gibran's concept, and who, quite plainly, did not. Untranslability could be also revealed at the semantic and intellectual levels. I consider that this typical example could highlight an extremely significant feature in literary translation. Gibran says, "Silences and not silence", and this is intentional. If Gibran were an undemanding poet, he would have used simply "silence", similar to the manner the first French translator did. The silences he refers to in this context are the different stages witnessed due to a profound transcendental meditation. By using silences, he alludes to an entire concept of religions where the soul has to undergo many stages of silence in order to be fully present. Gibran with this simple "silences" is evoking a philosophical issue that relates to his life and personal spiritual beliefs and philosophical thoughts. Gibran's phraseology or word usage was not employed randomly, according to the Italian translator F. Medici in one of his interviews (Gualdoni, 2005). The difficulty residing in such a text is going beyond or surpassing a simplistic, effortless translation of a complex poetic work. Many translators translated The Prophet of Gibran without stopping at philosophical features, which resulted in making their renditions quite different from the intended meaning of the original text. In this particular example, some would argue that Gibran is evoking a Sufi ideology. All the abovementioned translations used "silences" in its plural form, except for the mentioned French translator, who definitely did 
not entirely understand Gibran, and the Arabic translation, which is obliged to use the word "Sukun" in its singular form for linguistic issues. To support this interpretation, it deemed essential to examine, as researchers in language and translation studies, Gibran's numerous paintings. We then came to the conclusion that approximately $80 \%$ of his paintings portrayed individuals with their eyes closed. Perusing closer Gibran's vision, writings and interpretation, God's proximity prevents human beings from seeing Him. Closed eyes seemingly signify foraging God in one's spiritual realm. Closed eyes denote an inner, profound search that is far removed from the external and meaningless reality surrounding us. This concept is taken from Buddhism (as cited in The Buddha and His Teachings, 1998). By the use of this simple word in the plural form, one can sum up Gibran's entire thoughts and vision of life. This truth extends beyond what Venuti first described in translation as domestication and foreignization. Gibran's intentions could distinctly be comprehended: Gibran's writings and philosophy are patently aimed at a global notion. He never preferred the East - his beloved homeland Lebanon - to the West (the USA), where he lived a large part of his life. He attempted to merge both domains into a unique vision, belief, and global ideal that transcend differences. It is similar to appropriating ideas and concepts from a diversified source and eventually placing them jointly in the Human Unified Thought. Such an explanation occurs just to prove a feature in literary translation: in order to be a good literary translator, it is insuficient to merely understand the surface significance of a text, one has to associate intensely with the target object of the translation, thus grasping the texts' essence and vitality. As previously mentioned, Gibran was among the writers, poets and authors that were keenly aware of their word usage. This feature should have been thoroughly taken into account by translators before proceeding with their work. Mikhail Naimy (1975) mentioned in this context that The Prophet is not to be simply approached as a book of instructions; otherwise, no justice would be rendered to it. Its greater value lies in the mould in which those instructions are cast. The analysis is so far at the lexical level since the rendition of words and terms from a source language to a target language is a great proof of the interaction and barriers to overcome between languages and different cultures.

At this level, as I proceeded with the lexical analytical analysis, I intended to employ three proper names as examples to prove that every word utilized or selected by Gibran has a specific meaning, background, rich references and cultural connotation. Ignoring those factors is a major failure, and what applies to this text applies as well to the literary field as a whole. Gibran used a key character in The Prophet named "Almitra". Unintenionally, he wrote it as one word in the English language, quite definitely borrowing the word from Arabic. Translators rendered it as it is in the target language but few truly comprehended what it refers to in order to enable, at a later stage, an enhanced understanding of some concepts that led to a more faithful translation. Almitra is linked in some interpretations to a pivotal woman in Gibran's life called Mary Haskel — a constant, dependable guiding spirit to him, "Mary Haskel, subsequently became Gibran's confidante, patron and benefactor" (Bushrui, 2012). This actually very subjective explanation is not fully complete. Almitra recalls the form in the Arabic language that signifies rain that possesses an extremly purifying effect. In addition to that, Almitra represents the Goddess of Zoroaster--also known as Zarathustra - that denotes reconciliation and friendship (Dahdah, 1993). Except for the Italian translator, F. Medici, and the French translator, Jean- Pierre Dahdah, who fathomed the intended meaning, all translators with no exception wrote it as "Almitra". Al in the Arabic language is the definite article that used to mean "divinity" as originally everything was defined by the divinity feature that represents it. (Dahdah, 1993) Almitra is the oriental name given by Gibran to this distinguished woman. The study shows that most translators did not understand the article "Al" and they attach it to the word as if it were part of it. Going back to our claim that some words are difficult to render to the target language, I have to mention at this level that this obviously easy word's hidden connotations and cultural background make the concept as a whole, if not culturally understood, a complete failure. In addition, the linguistic intricacy that exists at this level and that deals with linguistic differences make it even more challenging for translators.

Another example chosen to highlight the fact that the literary field is the most challenging of all translations, is that of "Al-Mustafa" الهصطفى, the chosen and beloved, the first word employed in The Prophet. Gibran desired this work, as previously stated, to represent the entirety of his philosophical thought. His book is considered mystical. Besides, AlMustafa has a close link to the Sufi doctrine (Dahdah, 1993). Translators cannot while translating this book in particular search for sophisticated expressions that rhyme suitably; accordingly, they have to be exceedingly concise concerning the terms or vocabulary used. Gibran says to Mary Haskell that he is not interested in saying through his Prophet beautiful things but true ones instead (Hilu, 1972). Some translators failed to understand the sense or intention behind the choice of the name Al-Mustafa, and thus, duly misinterpreted it. For instance, the first Italian translation in 1936 names the hero, Ali Mustafa; it totally ignores the fact that Al-Mustafa signifies not any chosen person but the one and only. Gibran wished to provide a soul to a fusion between religions, in particular Christianity and Islam. "The reality is that it is a work of remarkable compassion, insight, hope and inspiration, with a timeless message that combines the dignity of the Christian Bible and the wisdom of the Sufis of Islam" (Bushrui, 2012). Unifying and providing a body and soul to the perfect human being resulting from a Sufi notion by excellence was his ultimate target.

The same interpretation applies to the month of Lelool. Gibran employed a phonetic system that cannot be used in other languages besides English, using the procedure of exotism (Venuti, 2008). Yet, all translators retained it as such without supplying it its value or relevant true meaning. As translators, they had either to transliterate correctly or simply translate. It is preferable to call attention to the month of September as is rather than translate it into Italian or French, hence creating a big loss in the translation process. Using the identical Anglophone forms in Italian or French or 
Spanish is meaningless. The month of Ielool sounds exotic and attractive but only in English; I consider it cannot be applicable to other foreign languages. I cannot but mention the Italian version of Medici and the French version of Dahdah that appropriated the Arabic sound and bestowed it its true shape; that is what we call exotism and uttered aylul in Italian and Ayloul in French perfectly.

Another cultural reference of major import is the name of the city of Orphalese. Few scholars understood the real meaning of the name of the city — many opted for a geographical explanation. The most logical evocation, tracing the story of Gibran's life, is New York (Dahdah, 2003). Orphalese, the name of a metaphoric city, represents the Occident, the materialistic Occident as he views it. It is nothing less than the city he willingly wishes to abandon in order to head towards his blessed land. He ardently desires to return to his beloved land, Lebanon. Orphalese could have been related to Orphan, which is also the land deprived of spirituality, the closed city. Using the name Orphalese, Gibran is not only confering about the Orient or the Occident, but about the Human Being, a spiritual entity. Orphalese could also represent Jerulasem in Arabic اور اشليم. Gibran perhaps wished to integrate a reference to one of holy cities of the three monotheist religions in his monumental book (F. Medici, personal communication, 2017). Referring to the cultural elements that prohibit sometimes a true comprehension of the text, a vitally informative example toward the end of the book has to be highlighted. This example is a clear response to my claim that some terms or expressions are so hard to render into the target language and give an importance to the literary translation field by making it one of the hardest tasks. This concept was interpreted and translated by most decoders. The majority or translators rendered simply the literal superficial meaning; however, one has to surpass the surface wordings to interpret well.

The book ends this way:

"A Little while, a moment of rest upon the wind, and another woman shall bear me."

The Italian Translation, with a clear understanding of the concept says:

"Un momento ancora, un attimo di calma del vento, e un' altra donna mi partorirà" F. Medici

The French first version by Paul- Jean Franceschini states:

"Un instant, un instant fugitive, un bref repos sur l'aile du vent, et dans son sein me portera une autre femme."

The French second version by Jean- Pierre Dahdah states:

"Un petit instant, un moment de repos sur le vent, et une autre femme me portera en son sein."

The French third version by Janine Levy

"Un court instant, un moment de repos sur le vent, et une autre femme me donnera naissance."

The Arabic version by Antonios Bashir:

" قليا و لا ترونني، وقليلا وترونني، لان امر أة أخرى ستلدني"

The second Arabic version by Sarwat Akacha:

"أجل، هنيهة، بل لحظة قصيرة أخلد فيها الى السكينة على منن الريح، ثم تحمل بي امر أة أخرى "

c. Discussion

The above-mentioned examples and straight translations serve to highlight the philosophical thought of Gibran and endeavor to interpret his own ideas in the target languages in accordance to them. In other words, one returns to this existence or world through reincarnation, according to the Druze doctrine. I am not certain to what extent the notion was understood but it evokes life, death, and eventually rebirth or reincarnation. The translator ought to have viewed the text as being a religious, sacred one, not simply as poetry or other literary genre. A simple addition by mostly all translators to the notion of (bringing me back to life) could have shown that the concept is clear. Most translators mentioned another woman who gives him life. I consider the info as incomplete as it confuses the audience that is unaware of Gibran's philosophical inclinations. How can another woman give him life? This is an untranslatable philosophical feature that has to be dealt with very meticulously. Back to our initial claim, one can never dissociate a text from its cultural backgroung and this is the added value and biggest challenge of literary translated texts. Had the author not created his Prophet in a poetic form, it would have been regarded or classified as a sacred text; indeed, for many, it is perceived as such. In an interview, the Italian translator Medici (2005) states that The Prophet will never be forgotten or old fashioned. This is a controversial issue exhibiting Gibran's inclination towards reincarnation, or perhaps only a metaphor or reference to the Druze doctrine in addition to the indo-buddhist religion. It undoubtedly indicates Gibran's enormous interest in India. In one of many letters addressed to his Arabic translator, Antonios Bashir, he referred to The Prophet as a big success to be ranked at least with that of Mahatma Gandhi. He also referred to Buddha and the Goddess Kali. I face at this level an untranslatable hidden meaning. Reincarnation was not even hinted on by most translators. Gibran wanted intentially to introduce the doctrine and part of his belief by the end of his book. This is the challenge of competent literary translator and eventually the arduous part of their task. A historic review regarding the retranslation of The Prophet, had its reasons highlighted. The examples exposed at this level will answer one of the research controversial issues that questions the utility of many retranslations at the level of one language. My typical example is the Italian versions, il Profeta, since it appeared throughout history many times in the same language. Why do translators value retranslation if the text has already been translated several times? It is important to mention that Gibran's standing in Italy, as in the rest of the West, is related mostly to the great success of The Prophet. The first Italian edition of The Prophet (Il Profeta) was published in 1936, five years after the author's death. (Medici, 2013). The Prophet of Gibran figures in numerous scholarly Italian articles as follows: 
- The Prophet (New York: Alfred A. Knopf, 1923). - Il Profeta, preface by Augusto Mancini, trans. E. Niosi-Risos (Lanciano: Rocco Carabba, 1936).

- Il Profeta, trans. Salvatore Cossù (Roma: Kossù, 1966). - Il Profeta, preface by Carlo Bo, trans. Gian Piero Bona (Parma: Guanda 1968).

- Il Profeta, introduction and commentary by Suheil B. Bushrui, trans. Ariodante Marianni (Milano: Rizzoli, 1993).

- Il Profeta, trans. Piera Oppezzo and Nicola Crocetti (Milano: Mondadori 1993).

- Il Profeta, trans. and commentary Paolo Ruffilli (Cinisello Balsamo: Edizioni San Paolo, 1989).

- Il Profeta, preface by Adonis, trans. Davide Rondoni (Milano: Corbaccio 2000).

- Il Profeta, trans. and commentary Isabella Farinelli (Milano: Paoline Editoriale Libri, 2001).

- Il Profeta, trans. and commentary Hafez Haidar (Casale Monferrato: Piemme, 2002). - Il Profeta, trans. and commentary Francesco Medici (Cinisello Balsamo: Edizioni San Paolo, 2005).

As stated in the work of Deane Cox, quoting from Venuti, "to retranslate is to confront anew and more urgently the translator's ethical responsibility to prevent the translating language and culture from effacing the foreigness of the foreign text (Deane Cox, 2014, p. 14). Returning to our case study on the Italian versions, "with every reading and each retranslation, the source text is pluralized and one new and possible text comes to light. In this sense, it is the impermanence of the original, and not the deficiency of translation, which gives impulse to the reiterativre act of retranslation." (Deane Cox, 2014, p. 192)

However, this is not totally the opinion of the Italian translator Francesco Medici, in an intervention commenting about the 2005 translation of The Prophet: "I wanted Gibran to be understood as a poet and a person. I truly appreciate all translations made since 1930 and they are numerous. Since that date, giving the fact that Gibran is well- known in Italy, the unique concern of translators was always to renovate the archaic translation. Only in Italy, the Italian translations and renditions of The Prophet are beyond hundreds. Mine came to draw Gibran, as I understood him after conducting many investigations about him as a person. Slightly before my translation in 2005, a beautiful translation appeared. The only default it had, and I consider it major, is that it limited Gibran. It only viewed him from a limited Catholic view. It did not really understand his religious inclinations. Besides, in many Italian translations, I notice the absence of stylistic simplicity as well, the absence of Gibran's true persona" (Gualdoni, 2005). In Medici's case, like in many other retranslations, be it mainly a "passionate recreation" within the limit of the respect of the sacred meaning, different stances occur when it comes to the utility of retranslation in general. However, study reveals that retranslation needs to be examined case per case in order to view, assess and determine its importance and utility. In the case of The Prophet, the depth of the cultural aspects, the strength of the ideas and themes raised in the book and the immortality of Gibran with his Prophet incited many translators to recreate this sacred book, seaking each time to try to touch on Gibran's thoughts and philosophy. With each retranslation, I could observe an attempt to be closer to his thoughts. It deems also very important at this level as well, to mention, a revelation of an unpublished discovery by two researchers, as a result of years of research. Glen Kalem (Sydney-Australia) and Francesco Medici (Bari-Italy), who are official members of the International Association for the Study of the Life and Work of Kahlil Gibran (University of Maryland, USA) have discovered that the Lebanese - American writer and poet Kahlil Gibran's The Prophet, long believed to have been translated into roughly 40 to 60 languages, out of which 50 languages already exist at the Gibran museum in Bcharre, Lebanon- has in fact been translated into 110 original first editions in different languages and dialects, making it one of the top ten most translated books of all times, and making Gibran one of the most translated poets in the world. This exciting discovery follows years of meticulous research by Kalem and Medici. (available along with the full list of translations as an annex to this study handled to us by the researchers). This huge number of translation per language and retranslations within the same language prove that it was necessary to render this work worldwide. There must be a reason that goes beyond linguistic, cultural and stylistic study. II believe that such endeavours were seeking the internalization of his message.

The next step in a work of such complexity is to uncover the equivalence or appropriate translations to untranslatable expressions or difficult concepts, as Christine Durieux (2010) explains excellently in her article, "Negocier un compromis".

\section{d. Concluding remarks}

Gibran was fully aware of how hard the translation task is. Gibran himself used to care a great deal about the quality of translation of his literary works. Gibran's letters to Archbishop Antony Bashir were unknown and unpublished until November 11, 2004, when they appeared in the original Arabic in the Lebanese daily newspaper «al-Nahār» («alMulhtaq») (Medici, 2010). Bashir was the first official translator of Gibran's works authorized by Gibran himself to translate from English into Arabic. This information is disclosed to emphasize the deep relation that has to occur between the writer and translator. However, his text was translated by two other translators. Here is an example that clealy indicates how meticulous Gibran was when it involved the translation of his thoughts and work. I knowingly selected this letter to demonstrate how Gibran himself acknowledged the creativity or ingenuity of the translator and his exacting task.

O Dear Brother,

Your translation of The Prophet is an act of kindness towards me that I will gratefully remember as long as I live. My hope is that the readers of the Arabic language will appreciate your literary enthusiasm and afford it its due worth. In 
my judgment, the translator is a creator, whether people acknowledge this or not. As far as I am concerned, the most deserving of all people to write the introduction is you because he who spends days translating a book from one language to another is certainly the most knowledgeable of all people about the merits and shortcomings of that book. This is my opinion. However, I ask that you please do what you wish concerning the introduction and the excerpts from the American newspapers (...)

Write to me when you find the means to write for you know that I find exceeding pleasure in listening to your news. Please accept my love accompanied by my best wishes.

May God keep you safe, for you are a dear brother,

Gibran Kahlil Gibran

New York, November 10, 1925

\section{CONCLUSION}

I conclude my study by stating that the development of this era starts from what is untranslatable in the intercultural dialogue, in particular the allusions and cultural references (Durieux, 2010). My study consisted of an attempt to shed light on the importance of literary translation, placing and considering it among the hardest in the translation field, and raising many critical issues (cultural, philosophical, existential) in order to situate it at its rightful, proper level. Aporias in the translation of poetic, religious or philosophical concept were raised, translations that have been revisited were also mentioned; some stances regarding retranslation were exposed and some gaps and problems were highlighted. My study's main objective is to place the immortable book, The Prophet, of the Lebanese-American renowned author Gibran Kahlil Gibran at its right level, given the big number of translations and retranslations and given its popularity since 1923. How can a simple book that was released in 1923 still be answering today's needs? The ground is open for more and more studies in this field that would enlighten even more the endeavours of this research. Will today's political struggles and problems still find answers twenty years later? We should establish that this book should be a bible for literary thoughts and a reference and central corpus in translation studies. I hope more research will be made in the future to shed light on similar cases in the literary field.

\section{APPENDIX}

The Prophet by Kahlil Gibran translated into 110 languages $\left(1^{\text {st }}\right.$ editions)

Edited by Glen Kalem and Francesco Medici by Chronological Order

(The International Association for the Study of the Life and Work of Kahlil Gibran)

\begin{tabular}{|c|c|}
\hline City & Year \\
\hline Munich & 1925 \\
\hline Cairo & 1926 \\
\hline Paris & 1926 \\
\hline The Hague & 1927 \\
\hline Warsaw - New York & 1929 \\
\hline Shanghai & 1931 \\
\hline Santiago, Chile & 1932 \\
\hline Prague & 1932 \\
\hline Stockholm & 1933 \\
\hline Buenos Aires & 1933 \\
\hline Mexico City & 1934 \\
\hline Lanciano (Chieti) & 1936 \\
\hline Bruxelles & 1943 \\
\hline Istanbul & 1945 \\
\hline Jakarta & 1949 \\
\hline Washington, D.C. (USA) & 1951 \\
\hline Hubli, India & 1953 \\
\hline Beirut & 1954 \\
\hline Pretoria & 1955 \\
\hline Ibagué & 1956 \\
\hline Beirut & 1956 \\
\hline Kabul, Afghanistan & 1957 \\
\hline Reykjavík & 1958 \\
\hline Pakistan & $1961(1340)$ \\
\hline Tehran & $1962(1341)$ \\
\hline Rio de Janeiro & 1963 \\
\hline Oslo & 1967 \\
\hline Lima & 1967 \\
\hline Hämeenlinna & 1968 \\
\hline Bangkok & 1968 \\
\hline Secunderabad (India) & 1968 \\
\hline Bratislava & 1971 \\
\hline Dar es Salaam, Tanzania & 1971 \\
\hline Tokyo & 1972 \\
\hline Barcelona & 1974 \\
\hline
\end{tabular}




\begin{tabular}{|c|c|}
\hline Tel Aviv & 1975 \\
\hline Toronto & 1975 \\
\hline Manila & 1975 \\
\hline Kapellen & 1977 \\
\hline Seoul & 1978 \\
\hline Braga & 1978 \\
\hline Ljubljana [i. e.] Maribor [Slovenia] & 1978 \\
\hline Madrid & 1980 \\
\hline Jakarta & 1981 \\
\hline Johannesburg & 1983 \\
\hline Antelias (Lebanon) & 1983 \\
\hline Boucherville [Québec] & 1983 \\
\hline Kochi (India) & 1983 \\
\hline Johannesburg & 1983 \\
\hline Olten & 1984 \\
\hline Zagreb & 1985 \\
\hline Switzerland & 1985 \\
\hline Tórshavn, Faroe Islands (Denmark) & 1986 \\
\hline Copenhagen & 1987 \\
\hline Vienna & 1987 \\
\hline Moscow & 1989 \\
\hline Montevideo & 1990 \\
\hline Bucarest & 1991 \\
\hline Algiers & 1991 \\
\hline Budapest & 1992 \\
\hline Skopje & 1993 \\
\hline Midnapore, India & 1993 \\
\hline Vietnam & 1994 \\
\hline Guwahati (India) & 1994 \\
\hline Belgrade & 1995 \\
\hline Kiev & 1995 \\
\hline Sofia & 1997 \\
\hline Tallinn & 1997 \\
\hline Vilnius & 1998 \\
\hline Baghdad & 1998 \\
\hline Patiala & 1999 \\
\hline France & 1999 \\
\hline Budapest & 2000 \\
\hline Stockholm & 2001 \\
\hline Kashgar, China & 2001 \\
\hline Jönköping (Sweden) & 2002 \\
\hline Tirana & 2003 \\
\hline Colombo & 2004 \\
\hline Kathmandu & 2005 \\
\hline Plettenberg Bay (South Africa) & 2007 \\
\hline Plettenberg Bay (South Africa) & 2007 \\
\hline Plettenberg Bay (South Africa) & 2007 \\
\hline Plettenberg Bay (South Africa) & 2007 \\
\hline Yerevan & 2008 \\
\hline Sta Venera [Malta] & 2008 \\
\hline Arantzazu (Basque Country) & 2008 \\
\hline Aurangabad, India & 2009 \\
\hline New Delhi & 2009 \\
\hline Dhaka, Bangladesh & 2009 \\
\hline Cebu City (Philippines) & 2009 \\
\hline Chennai (Madras, India) & 2011 \\
\hline Addis Ababa (Ethiopia) & 2011 \\
\hline Quezon City, Philippines & 2011 \\
\hline Zinswiller (France) & 2013 \\
\hline Bethesda (Maryland, USA) & 2013 \\
\hline Naga City & 2013 \\
\hline Ahmedabad (Gujarat, India) & 2013 \\
\hline Baku & 2014 \\
\hline Paris & 2014 \\
\hline Tizi-Ouzou (Algeria) & 2014 \\
\hline Berlin & 2015 \\
\hline Monza & 2015 \\
\hline Peterborough, England? & 2015 \\
\hline London & 2016 \\
\hline Andorra la Vella & 2016 \\
\hline Oslo & 2017 \\
\hline Santiago de Compostela, Spain & 2018 \\
\hline
\end{tabular}




\section{REFERENCES}

[1] Bashir, A. (1923). date and place of publication and publishing house are not mentioned.

[2] Benjamen, W. (2012). The Translator's Task. In L.Venuti, The Translation Studies Reader (p.75). London and New York: Routledge Taylor and Francis Group.

[3] Blommaert, J. and Bulcaen, C. (2000). Critical Discourse Analysis. Annual Review of Anthropology, 29, pp. 447-466.

[4] Bushrui, S. (2012). The Prophet: A new Annotated Edition. London: Oneworld Publications.

[5] Bushrui, S. (1970). An Introduction to Kahlil Gibran. Beirut: Dar El- Mashreq.

[6] Dahdah, J.P. (1993). Le Prophète. Aix-en- Provence: Editions du Rocher

[7] Deane Cox S. (2014). Retranslation Translation Literature and Reinterpretation. Bloomsbury. UK.

[8] De Pedro, R. (1999). The Translatability of Texts: A Historical Overview Meta, 44(4), 546-559. https://doi.org/10.7202/003808ar.

[9] Durieux, C. (2010). Traduire l'intraduisible: négocier un compromis. Meta journal, Volume 55, number 1.pp 23-30

[10] El Hage, G. (2005). Gibran's Unpublished Letters to Archbishop Antonious Bashir, in the Journal of Arabic Literature, Vol. 36, No. 2. Brill Publishers, Leiden, the Netherlands, pp.172-182.

[11] Farghal, M \& Almanna, A. (2015). Contextualizing Translation Theories. Cambridge Scholars Publishing. UK.

[12] Franceschini, P.J. (1995). Le Prophète. Edition Beirouth: FMA

[13] Fairclough, N. (1989). Language and Power. London and New York: Longman.

[14] Gualdoni, L.(2005). La voce del Profeta da Oriente a Occidente, interview with Francesco Medici, Stilos, pp.8-21.

[15] Hatim B. (2001). Teaching and Researching Translation. London and New York: Routledge

[16] Hilu, V. (1972). Beloved Prophet. Great Britain, London: Alfred A.Knopf Inc.

[17] Kahlil, G. (1929). Der Novi, translated into Yiddish by Isaac Horowitz, Warsaw (Poland): Biblioteka Jaczkowskiego

[18] Levy, J. (1993). Le Prophète. Istanbul: Librairie Générale Française

[19] Medici, F. (2005). Il Profeta, Cinisello Balsamo: Edizioni San Paolo

[20] Medici, F. (2012, May). Gibran in Italy, in The Enduring Legacy of Kahlil Gibran. Papers delivered at the Second International Conference on Kahlil Gibran: Reading Gibran in an Age of Globalization and Conflict, University of Maryland, College Park, 2013 pp. 182-203.

[21] Medici, F. (2015). Poeti arabi della diaspora, , versi e prose liriche di Kahlil Gibran, Ameen Rihani, Mikhail Naimy, Elia Abu Madi, Bari: Stilo Editrice.

[22] Mossop, B. 2001. Revising and editing for translators. Np: St Jerome Publishing.

[23] Munday, J. (2007). Introducing translation studies. London and New York: Rutledge.

[24] Naimy, M. (1975). Gibran at his peak. In Gibran of Lebanon: New Papers, p.9 Eds. Suheil Bushrui and Gotch Beirut: Librairie du Liban.

[25] Nasr, N. (2018). Gibran Kahlil Gibran The Prophet: Arabic \& French Translations: A Comparative Linguistic Analysis, Lebanon: Librairie du Liban Publishers.

[26] The Buddha and his teachings. (1998). Retrieved in December 2017 from: http://www.buddhanet.net/pdf_file/buddhateachingsurw6.pdf.

[27] Venuti, L. (2008). The Translator's invisibility: A History of translation. London and NewYork: Routledge.

[28] Vinay, J. P. and Darbelnet, J. (1958). Comparative stylistics of French and English. Np.: Didier Harrap.

[29] Von Goethe, J.W (2012). Translations. In L.Venuti, The Translation Studies Reader (p.75). London and New York: Routledge Taylor and Francis Group.

[30] Wilss, W. (1982). The science of translation: problems and methods. Tubingen: Narr.

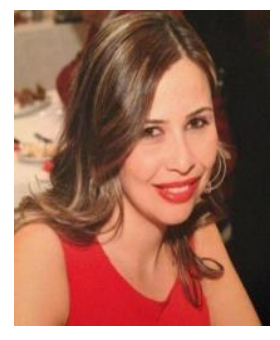

Maya El-Hajj is an Assistant Professor at the Faculty of Humanities, Department of English and Translation. She holds a doctorate in Translation Studies from the Holy Spirit University- Kaslik, and a Certification of Competence in Teaching Italian as a foreign language or second language (CEDILS), from the Ca 'Foscari University of Venice, Italy. Her main interest is the effect of culture on languages. Her main teaching area is Translation and Languages, mainly English, French, Arabic and Italian. In addition to her interest in Translation and Teaching, Dr. El Hajj is particularly interested in lexicology-lexicography, a vast field hardly exploited nowadays in the Arab world. Her doctorate dissertation, which is entitled "Etude comparative des dictionnaires bilingues et monolingues", addresses specifically that field. Dr. El Hajj has given lectures and conferences in many academic institutions in Lebanon, England, Greece, France, Georgia and Italy. 